\title{
Peacebuilding and the Responsibility to Rebuild
}

\author{
RAMESH THAKUR*
}

The Responsibility to Protect (R2P) principle, encompassing the three symbiotically linked responsibilities to prevent, respond and rebuild, was unanimously adopted at the United Nations World Summit in 2005. The responsibility to rebuild needs to be re-elevated to prominence as an integral component of R2P: conceptually, normatively and operationally; and its institutional homes in the UN system and the Secretary-General's role clarified. The 2009 three pillar formulation of R2P works well in most contexts, but is problematic in that it buries and loses sight of the critical importance of the original ICISS third 'responsibility to rebuild' and reconstruct war-raved societies to the point of being viable and self-sustaining once again. Because R2P was adopted at a world summit, I begin by highlighting the distinctive attributes of summit diplomacy. Next, I derive some key lessons from the major international interventions of the twenty-first century and recall the context in which R2P was originally formulated in order to highlight the distinctive features of its contribution to international policy. I then describe three dimensions of the responsibility to rebuild - recovery, reconstruction and reconciliation - and the strategies and steps needed for the rebuilding agenda. Recalling that Security Council authorization of R2P coercive operations is a non-negotiable prerequisite, I suggest that the responsibility to rebuild can be reintroduced and implemented through the administrative and political leadership roles of the Secretary-General.

Keywords: Peacebuilding, Responsibility to Protect, Summit Diplomacy, the United Nations, International Intervention

*Emeritus Professor at the Crawford School of Public Policy, The Australian National University. This paper was presented as the Keynote Speech at the Korea International Studies Association Annual Conference, November 16, 2018. E-mail: ramesh.thakur@anu.edu.au

DOI: 10.16934/isr.19.2.201812.1 


\section{PEACEBUILDING AND THE RESPONSIBILITY TO REBUILD}

The failure of the UN's principal political organs - the UN Security Council (UNSC) and General Assembly (GA) - to function as envisaged places a disproportionate burden on the shoulders of the Secretary-General (SG), an office with little power but considerable influence. This has been particularly evident in the story of the origins, adoption and development of the Responsibility to Protect (R2P) as the central organizing principle for the international community to respond to humanitarian atrocities being committed inside sovereign jurisdictions. First articulated in the report of the International Commission on Intervention and State Sovereignty (ICISS) in 2001, as an 'umbrella' principle R2P was broken down into three constituent responsibilities, each being given its own chapter in the report: to prevent, react and rebuild.

The R2P principle was endorsed unanimously at the 2005 UN world summit. Paragraphs 138 and 139 of the summit's outcome document serve as the functional equivalent of the 'constitution' of R2P. In these, the responsibilities to prevent and react were endorsed but not to rebuild and while the UNSC would be responsible for implementing R2P, the GA would 'continue consideration of the responsibility to protect $\cdots$ and its implications'. Taking the 2005 document as the agreed intergovernmental text, SG Ban Ki-moon's subsequent reports similarly neglected peacebuilding as an integral component of R2P. His 2009 report reformulated R2P in the metaphor of three pillars: the state's responsibilities; international assistance to the state; and collective international action when the state is unable or unwilling to discharge its sovereign responsibility to international standards (Ban 2009).

The responsibility to rebuild needs to be re-elevated to prominence as an integral component of R2P conceptually, normatively, operationally and institutionally. Because the three pillar conceptualization works better in most respects, any effort to reverse the current global understandings would be damaging and counter-productive. Instead, the original ICISS third responsibility can be reintroduced through the administrative and political leadership roles of the SG.

\section{SUMMIT DIPLOMACY}

Because R2P was adopted at a world summit, I begin by highlighting the distinctive attributes of summit diplomacy. Summits are necessary because of the growing interdependence among nations and interconnectedness among issues that cut across ministries and responsibilities, all of which cry out for collective management at the highest levels: 'problems without passports' (Annan 2009, 30-31) in search of solutions without passports. Summits are made possible by of 
advances in transport and telecommunications which facilitate also the active participation of civil society networks. Summits should make the most difference in those problem areas where leadership commitment is the critical variable, where the primary obstacle to identifying policy overlap and convergence and reaching consensus is the lack of an appropriate forum, and where speedy resolution is essential.

An appropriately structured and adequately prepared summit 'should get political leaders doing what they alone can do - making tough choices among competing interests and priorities' (Martin 2005, 6). With broad, overarching responsibilities, leaders, and only leaders, can best weigh priorities and seek to balance interests across competing goals, sectors, national and international objectives, and between the immediate, medium and long terms. ${ }^{1}$ Before the summit their engagement catalyzes officials to focus on and resolve interagency differences, jurisdictional turf battles and veto points. ${ }^{2}$ At the summit, their involvement makes it possible for states to bargain across issues in order to cut deals (that is, trade apples for oranges). Among leaders, summit agreements can lead to diffuse reciprocity: not tit-for-tat bargaining but rather a general atmosphere where the interests of counterparts are taken carefully into account across a range of issues. After the summit, their commitment to the agenda invests it with legitimacy, prioritizes its implementation and can help to redirect resources even amidst fiscally constrained budgetary environments.

\section{R2P}

One of the most important developments in world politics in recent decades has been the spread of the idea that there exists a responsibility to protect people threatened by mass-atrocity crimes - vested in individual states at the national level and in the UN at the global level. Tyranny is not restricted to any particular religion, culture, civilization or gender. Political rule based in terror rather than citizen's welfare is a universal moral failing. The Westphalian system of sovereign states spread from Europe to cover the whole world. Because it sanctified the ability of tyrants to rule by terror - free from external restraints and counter-measures - the need arose for a matching universal norm to ban and stop atrocities. For advocates, R2P is a poster child of liberal internationalism, summoning forth the better angels of human nature to save strangers in distant lands within a rules-based global order. For critics, it is the enabler of choice for powerful countries to appropriate the language of humanitarianism when violating the sovereignty of weak nations.

The notion that R2P is a resurrection of Rudyard Kipling's 'white man's burden' can itself be racist and offensive. It denies agency to developing countries, insisting they can only be victims. It suggests their citizens should 
either be left to the mercies of thuggish leaders, or to the ad hoc geopolitical calculations of powerful Western countries, rather than to globally validated norms and due process. It ignores the origins of R2P, agreed in the aftermath of the 1994 Rwanda genocide, 1995 Srebrenica massacre and 1999 Kosovo intervention, and driven by African and European victims. It also ignores the indigenous traditions in many parts of Asia and Africa that hold rulers owe duties for the safety, welfare and protection of their subjects. For instance, the Hindu concept of rajdharma means duty of rulers - a point that was made by then-Prime Minister A.B. Vajpayee to the then-state Chief Minister Narendra Modi, of the same political party, in relation to his failure to protect 2,000 Muslims killed in targeted violence in Gujarat in 2002.3

The Genocide Convention converted the moral revulsion of the Holocaust - a failure of Western civilization - into a binding universal norm. The two humanitarian crises that most drove the push for R2P were the Rwanda genocide in 1994 and the Balkans atrocities bookended by the Srebrenica massacre in 1995 and the Kosovo intervention in 1999. One of these crises was African, the other European. R2P is a global norm that, in the allocation of solemn responsibilities of protection, does not discriminate on grounds of nationality, race or religion, but applies equally to all. As such it speaks eloquently to the highest UN ideals of international solidarity. Just as the UN is the symbol and site of the full family of nations, so R2P is an acceptance of the duty of care by all of us fortunate enough to live in zones of safety towards our fellow human beings trapped in zones of extreme danger.

Against the backdrop of a highly charged international controversy over NATO's self-proclaimed emerging new norm of 'humanitarian intervention' in Kosovo in 1999, ICISS calmed the troubled waters by redefining sovereignty as responsibility. We argued that states, as part of their sovereign duties, have the primary responsibility to protect all populations inside their borders; and the international community has a fallback responsibility if the state authorities prove unable or unwilling, or if they are themselves complicit in the atrocities. One of the key arguments for R2P was that while humanitarian intervention highlighted the rights and privileges of the intervening powers, $\mathrm{R} 2 \mathrm{P}$ prioritized the needs of the victims.

By rooting military intervention in human solidarity, R2P provided 'conceptual, normative and operational linkages between assistance, intervention and reconstruction' (ICISS 2001, 17). If interventions are genuinely motivated by humanitarian concerns as the primary goal (accepting that the real world is usually characterized by mixed motive situations), then their implementation implies solidarity across borders. Such solidarity, however, cannot begin and end with military intervention. It must also find expression at the pre-crisis point and be continued after the immediate crisis is over. 
Moreover, operationally R2P can be aligned to supplement UN peace operations whereas humanitarian interventions are closer to war fighting (ICISS 2001, 57-67). After intervention, the main mission of R2P military forces is transformed to provide the safe environment necessary for the restoration of good governance and the rule of law, with a transition of responsibility from military to civilian authorities as soon as possible.

\section{TWENTY-FIRST CENTURY INTERNATIONAL INTERVENTIONS}

Thus far the twenty-first century had witnessed major international interventions in Afghanistan, Iraq, Libya and Syria. All four countries have stopped functioning as sovereign states. The entire region has been consumed by sectarian, tribal and jihadist violence. All four cases involved foreign interventions in badly fragmented countries that deepened the sectarian fissures. The collapse of humanitarian ideals into sectarian bloodbaths has discredited externally directed liberal state-building as a normative enterprise, regardless of whether it is UN-authorized or unilateral.

Three common lessons can be drawn from these cases. The most important is the limited utility of the use of force. Non-R2P operations in Iraq and Afghanistan have been no more successful than the R2P-authorised mission in Libya. Syria proves that R2P does not guarantee collective UN action on all occasions when it is needed and justified. Nor, as Libya proved, does it guarantee successful outcomes when the UN does approve military action to protect populations at risk of slaughter. But nothing in recent history suggests going around the UN ensures success either.

If the primary pathology is the lack of local good governance institutions, the military is ineffectual and counter-productive: it destroys and degrades the fragile physical and institutional infrastructure that does exist. The second critical lesson therefore is that for major powers, going through the UN reduces the diplomatic transaction costs and contributes to the consolidation of the principle of a world governed by the rule of law in the use of force. The third important lesson, conversely, is that unilaterally reinterpreting a UN mandate to expand the mission and the means builds resistance; other countries resent being exploited as useful idiots and will withhold cooperation on future issues.

\section{THE RESPONSIBILITY TO REBUILD}

For countries coming out of protracted conflicts, the people are typically deeply traumatized, their economies wrecked, their infrastructure gutted, their political institutions highly stressed, and in some cases their communities bitterly divided. Almost half of all countries coming out of conflict relapse into armed 
violence within a decade of a peace agreement, owing both to pre-conflict characteristics that led to conflict in the first place, and to the post-violence legacy of the conflict itself (Collier 2004: 8-9). Most armed conflicts today are repeat civil wars (Themnér and Wallensteen 2015). The presence of a UN peace operation in a post-conflict country reduces the chances of it slipping back into violence (Doyle and Sambanis 2006; Fortna 2008). Yet the UN has not generally been able to move from initial stabilization, infrastructural reconstruction and the re-establishment of local governance institutions, to the more demanding goal of leaving behind self-sustaining structures of state that can implement economic growth and social transformation.

An excellent definition of peacebuilding is in the Brahimi Report: 'activities undertaken on the far side of conflict to reassemble the foundations of peace and provide the tools for building on those foundations something that is more than just the absence of war'(Report of the Panel on UN Peace Operations 2000). In the 2001 ICISS formulation, R2P rebuilding is conceptually and operationally indistinguishable from peacebuilding which has an earlier pedigree going back to SG Boutros Boutros-Ghali's Agenda for Peace (1992). The ICISS distinct contribution lay in elevating this into a political-cum-moral responsibility co-equal with the responsibilities to prevent and react. There is one additional significant difference. Under the ICISS R2P, prevention and intervention are general responsibilities shared by all states, but the responsibility to rebuild is particular to states undertaking military intervention. Similarly, while the responsibility for peacebuilding is diffuse and shared among all states, that for $\mathrm{R} 2 \mathrm{P}$ rebuilding is restricted to the intervening states that must remain engaged as long as necessary to achieve stability.

Without successful post-intervention peacebuilding, countries subject to interventions can become stuck in a 'conflict trap' of a cycle of ongoing armed conflict and economic decline. Peacebuilding can help to break the conflict trap and end these self-replicating cycles of violence. A scathing report by the UK parliament's foreign affairs select committee concluded that the NATO-led intervention in Libya in 2011 drifted into the unannounced goal of regime change, shirked a moral responsibility to help reconstruct Libya after Gaddafi's ouster, and contributed to the country descending into a failed state through political and economic collapse, sectarian warfare, humanitarian and migrant crises, and the spread of arms across the region (Wintour and Elgot 2016).

An R2P intervention either prevents or halts the commission of group-based atrocities. Thereafter, actions must be taken to consolidate the peace and create the institutions to prevent a recurrence of armed confrontation between former enemy groups. The underlying strategic vision informing all peacebuilding missions should be the restoration and development of effective, efficient and legitimate public institutions capable of delivering the necessary goods and 
services, assuring public safety and order, exercising monopoly control over the legitimate use of force, mediating intergroup competition, and promoting economic development.

Programs that do not take account of local priorities and exclude local personnel can create an unhealthy dependency on the intervening authority and stultify the regrowth of local institutions and the economy. In the long run, international actors in a post-conflict situation should aim 'to do themselves out of a job' (ICISS 2001, 45). While 'internationals' have the requisite resources to build a secure environment and begin the reconstruction process, the responsibility for their future lies ultimately with the local actors and populations.

ICISS disaggregated the responsibility to rebuild into three constituent components: recovery, reconstruction and reconciliation (ICISS 2001, xi). A major and urgent peacebuilding responsibility of any intervening force is to encourage economic growth, the recreation of markets and sustainable development. Rapid economic growth is dramatically effective in reducing post-conflict risks (Bigombe et al. 2000). Such growth can be promoted by international actors through aid and assistance in creating institutions and practices of good governance. International efforts need to be sustained for a minimum of 15 years to support most long-term institutional transformations (World Bank 2011, 193). Another urgent post-intervention task relates to the disarmament, demobilization and reintegration (DDR) of local security forces. The importance of this was starkly highlighted by the folly of the US occupying authority in disbanding Saddam Hussein's army in Iraq in 2003, with no effort to reintegrate the large number of soldiers.

Ensuring sustainable reconstruction and rehabilitation will involve the commitment of sufficient funds and resource and close cooperation with local people. Following DDR in the first phase, new national armed forces and police have to be rebuilt, integrating as far as possible elements of the formerly competing armed factions. It is just as important to build a non-corrupt and properly functioning justice system, including both the courts and police. The importance of transitional justice arrangements during an operation is now generally acknowledged, and the need to restore judicial systems as soon as possible thereafter.

Revenge killings and 'reverse ethnic cleansing', only too common as victimized groups attack those aligned to former oppressors, discredit and retrospectively delegitimize the intervention. In post-conflict countries, hostile groups must be socialized to live together peacefully once again; sharing power, engaging in bargaining, negotiation and accommodation instead of armed violence, and agreeing to resolve differences by constitutionally mandated peaceful means.

The liberal peace paradigm has proven to be unduly optimistic in some 
core assumptions. Hasty democracy promotion often generates perverse effects. For example elections, far from signifying and embedding the peace dividend, can create losers and winners and increase the likelihood of violence if the victors govern with a winner-take-all mentality that drives defeated groups to resume armed opposition. This is why the construction of legitimacy is an integral component of peacebuilding (Higashi 2015). The peacebuilding agenda must be sensitive to the competing bases and imperatives of domestic and international sources of legitimacy (Bose 2016).

\section{THE SG AS AN INTERNATIONAL ACTOR}

The office of the SG is 'the repository of international authority on the meaning and application of R2P' (Luck 2016, 303). With respect to global norms, universal values and international standards in particular, the SG has a unique bully pulpit both allowing and demanding a role and influence above and beyond the powers conferred on the office by the Charter and developed through intergovernmental practice. The two best exemplars of this have been Dag Hammarskjöld and Kofi Annan. ${ }^{4}$

Annan played a key role in the development of R2P as a global norm, while Ban promised to engage in 'the effort to turn promise into practice, words into deeds' (Ban 2008). The UN is both a site of and an actor in global governance (Thakur 2011). The SG can draw on these two elements of UN identity and exploit his position at the centre of a complex network of diplomatic relationships to be an active player in the construction and mid-course corrections of peacebuilding mandates as core components of R2P operations. SG Antonio Guterres should end the 'estrangement of peacebuilding and R2P at the UN' (Paris 2016, 513). He can provide broad overall management and oversight of their implementation, and coordinate the vast $\mathrm{UN}$ institutional machinery engaged in this multilevel and multi-stakeholder enterprise. His first avenue of influence to this end is through three key institutional entities that are part of the UN system today: the special adviser on R2P, the Peacebuilding Commission (PBC), and the Special Representatives of the SG.

Ed Luck $(2016,291)$ took 'the lead in framing both the normative and operational dimensions of R2P'. The two dimensions converge in peacebuilding and one of the early tasks for the new Special Adviser should be to draft a special report on this missing third responsibility, promoting international understanding of its importance as an integral element of R2P. The PBC's purpose is to identify countries sliding towards state collapse, institute measures to halt the slide and plan for and assist in the transition from war and conflict to peace and post-conflict peacebuilding. Unfortunately, it suffers from a crisis of credibilitycum-legitimacy. It has been lumbered with confused reporting lines and areas of 
overlap and duplication with existing departments.

As head of mission, the SRSG exercises delegated administrative and executive authority over all its components, functions and personnel. Working under the SG and through him to the Security Council, the PBC and the GA, the SRSG has both the opportunity and the responsibility to work with the UN humanitarian and development agencies, the World Bank, the bilateral and multilateral donor community, and the regional stakeholders, to identify strategies for building peace in order to convert the ceasefire agreement and/or peace settlement into sustainable peace that is more than just the absence of war (Peck 2016). If deemed necessary, the SRSG can also leverage the unique international authority and legitimacy of the SG to get buy-in from the private sector for regenerating economic activities and creating a functioning market once again. The SRSG cannot function simply as a passive recipient and implementer of mandates and orders. Instead, through creative interpretations of the mandate, and accurate and timely analysis of sensitive information and recommendations based thereon, SRSGs can actively shape both the peacekeeping and peacebuilding agendas.

R2P proved exciting from the start because it was fresh, challenging and potentially invaluable in saving strangers' lives. But because its hard edge involved the use of force inside sovereign jurisdictions, it was inevitably also provocative, controversial and confronting. In consequence politics is at the heart of efforts to analyse and respond to crises through the R2P lens. This shapes the SG's interaction with the Security Council. If the P5 are united, the SG cannot be an alternative locus of dissent. If they are deeply engaged but divided, the SG cannot construct an artificial consensus. But if they are relatively disengaged and detached, the SG may be able to navigate a tricky pathway through to an imaginative solution.

\section{CONCLUSION}

Controversies notwithstanding, R2P has a secure future because in origins it was essentially demand-driven and, unhappily, the demand for it is unlikely to disappear anytime soon (Thakur 2016). R2P must be 'understood to include post-intervention peacebuilding, not as an optional add-on but as an integral part of the doctrine, just as the ICISS had suggested' (Paris 2016, 519). The UN has a big comparative advantage in designing the template for post-intervention rebuilding strategies; the amount, type and timing of the required international economic, military and governance assistance; and oversight of delivery and implementation. Peacebuilding is one of the tools whereby the UN, without reaching for heaven, can help people trapped in post-conflict nightmares to escape from hell on earth. 


\section{REFERENCES}

Annan, Kofi. 2009. "Problems without Passports." In Foreign Policy 132: 30-31. Annan, Kofi. 2014. We the Peoples: A UN for the 21st Century edited by Edward Mortimer. London: Paradigm Publishers.

Bigombe, Betty, Paul Collier and Nicholas Sambanis. 2000. "Policies for Building Post-Conflict Peace." Journal of African Economies 9(3): 32348.

Bose, Srinjoy. 2016. "Death by a Thousand Cuts or Dance of the Seven Veils? Legitimacy and Generation of Authority in Afghanistan's Statebuilding Enterprise, 2001-2014.” (Ph.D. thesis, Australian National University). Boutros-Ghali, Boutros. 1992. An Agenda for Peace. New York: United Nations. Collier, Paul. 2004. "Development and Conflict." Oxford: Centre for the Study of African Economies, Department of Economics, Oxford University.

Collier, Paul, Lani Elliot, Havard Hegre, Anke Hoeffler, Marta Reynal-Querol and Nicholas Sambanis, 2003. "Breaking the Conflict Trap: Civil War and Development Policy." World Bank Policy Research Report. Oxford: Oxford University Press.

Cooper, Andrew F. and Ramesh Thakur. 2013. The Group of Twenty (G20). London: Routledge.

Doyle, Michael C. and Nicolas Sambanis. 2006. Making War and Building Peace: The United Nations Since the 1990s. Princeton: Princeton University Press.

Feinberg, Richard. 2013. "Institutionalized Summitry." In The Oxford Handbook of Modern Diplomacy edited by Andrew F. Cooper, Jorge Heine and Ramesh Thakur, 303-318. Oxford: Oxford University Press.

Fortna, Virginia Page. 2008. Does Peacekeeping Work? Shaping Belligerents' Choices after Civil War. Princeton: Princeton University Press.

Higashi, Daisaku. 2015. Challenges of Constructing Legitimacy in Peacebuilding: Afghanistan, Iraq, Sierra Leone, and East Timor. London: Routledge.

ICISS, 2001. The Responsibility to Protect. Ottawa: International Development Research Centre.

Ki-moon, Ban. 2008. "Secretary-General defends, clarifies "Responsibility to Protect" at Berlin event on 'responsible sovereignty: international cooperation for a changed world'." 15 July. New York: United Nations, Press Release.

Ki-moon, Ban, 2009. "Implementing the responsibility to protect: Report of the Secretary-General." In UN document (A/63/677, January 12).

Luck, Edward C. 2016. "Getting There, Being There: The Dual Roles of the Special Adviser." In The Oxford Handbook of the Responsibility to 
Protect edited by Alex Bellamy and Tim Dunne, 288-314. Oxford: Oxford University Press.

Martin, Paul. 2005. "A Global Answer to Global Problems: The Case for a New Leaders' Forum.” In Foreign Affairs 84. .

Paris, Roland. 2016. "The Blurry Boundary between Peacebuilding and R2P." In The Oxford Handbook of the Responsibility to Protect edited by Alex Bellamy and Tim Dunne, 509-523. Oxford: Oxford University Press.

Peck, Connie. 2016. "Special Representatives of the Secretary-General." In The UN Security Council in the 21st Century edited by Sebastian von Einsiedel, David M. Malone and Bruno Ugarte, 457-74. Boulder CO: Lynne Rienner.

Stahn, Carsten and Henning Melber, eds. 2014. Peace Diplomacy, Global Justice and International Agency: Rethinking Human Security and Ethics in the Spirit of Dag Hammarskjöld. Cambridge: Cambridge University Press.

Thakur, Ramesh. 2011. "Multilateral Diplomacy and the United Nations: Global Governance Venue or Actor?" In The New Dynamics of Multilateralism: Diplomacy, International Organizations, and Global Governance edited by James P. Muldoon, JoAnn Fagot Aviel, Richard Reitano, and Earl Sullivan, 249-65. Boulder: Westview.

Thakur, Ramesh. 2013. "A Balance of Interests." In The Oxford Handbook of Modern Diplomacy edited by Andrew F. Cooper, Jorge Heine and Ramesh Thakur, 70-87. Oxford: Oxford University Press.

Thakur, Ramesh. 2016. "Atrocity Crimes and Global Governance." In Why Govern: Rethinking Demand and Progress in Global Governance edited by Amitav Acharya, 138-56. Cambridge: Cambridge University Press. .

Themnér, Lotta and Peter Wallensteen. 2015. "Armed Conflicts 1946-2014." Journal of Peace Research 52(4): 536-50.

United Nations. 2003. Report of the Panel on United Nations Peace Operations (A/55/305-S/2000/809, 21 August 2000).

United Nations General Assembly. 2005. 2005 World Summit Outcome (A/RES/60/124, October 2005).

Wintour, Patrick and Jessica Elgot. 2016. "MPs deliver damning verdict on David Cameron's Libya intervention.” Guardian, 21 September 2016.

World Development Report. 2011. 2011: Conflict, Security, and Development. Washington DC: World Bank.

\section{ENDNOTES}

1 This paragraph draws on particular on Andrew F. Cooper and Rmesh Thakur, The Group of Twenty (G20) (London: Routledge, 2013) and Richard Feinberg, 'Institutionalized Summitry', in Andrew F. Cooper, Jorge Heine and Ramesh 
Thakur, eds., The Oxford Handbook of Modern Diplomacy (Oxford: Oxford University Press, 2013: 303-318).

2 For elaboration of a balance of interests as an alternative analytical construct to the national interest, see Ramesh Thakur, 'A Balance of Interests', in Andrew F. Cooper, Jorge Heine and Ramesh Thakur, eds., The Oxford Handbook of Modern Diplomacy (Oxford: Oxford University Press, 2013: 70-87).

3 The video is available at: www.youtube.com/watch? $\mathrm{v}=\mathrm{HJBItuHzUR0.}$

4 See especially Carsten Stahn and Henning Melber, eds., Peace Diplomacy, Global Justice and International Agency: Rethinking Human Security and Ethics in the Spirit of Dag Hammarskjöld (Cambridge: Cambridge University Press, 2014), and Kofi Annan, We the Peoples: A UN for the 21st Century, edited by Edward Mortimer (London: Paradigm Publishers, 2014).

4 This paragraph draws on particular on Andrew F. Cooper and Rmesh Thakur, The Group of Twenty (G20) (London: Routledge, 2013) and Richard Feinberg, 'Institutionalized Summitry', in Andrew F. Cooper, Jorge Heine and Ramesh Thakur, eds., The Oxford Handbook of Modern Diplomacy (Oxford: Oxford University Press, 2013: 303-318).

${ }^{4}$ For elaboration of a balance of interests as an alternative analytical construct to the national interest, see Ramesh Thakur, 'A Balance of Interests', in Andrew F. Cooper, Jorge Heine and Ramesh Thakur, eds., The Oxford Handbook of Modern Diplomacy (Oxford: Oxford University Press, 2013: 70-87).

4 The video is available at: www.youtube.com/watch?v=HJBItuHzUR0.

${ }^{4}$ See especially Carsten Stahn and Henning Melber, eds., Peace Diplomacy, Global Justice and International Agency: Rethinking Human Security and Ethics in the Spirit of Dag Hammarskjöld (Cambridge: Cambridge University Press, 2014), and Kofi Annan, We the Peoples: A UN for the 21st Century, edited by Edward Mortimer (London: Paradigm Publishers, 2014). 